\title{
Possible gas-phase syntheses for seven neutral molecules studied recently with the Green Bank Telescope ${ }^{\star}$
}

\author{
D. Quan ${ }^{1}$ and E. Herbst ${ }^{2}$ \\ ${ }^{1}$ Chemical Physics Program, The Ohio State University, Columbus, Ohio 43210, USA \\ e-mail: herbst@mps.ohio-state.edu \\ 2 Departments of Physics, Chemistry and Astronomy, The Ohio State University, Columbus, OH 43210, USA
}

Received 9 July 2007 / Accepted 17 August 2007

\section{ABSTRACT}

\begin{abstract}
Aims. With the Green Bank telescope (GBT), seven neutral molecules have been newly detected or confirmed towards either the cold interstellar core TMC-1 or the hot core source Sgr B2(N) within the last 1-2 years. Towards TMC-1, the new molecules seen are cyanoallene $\left(\mathrm{CH}_{2} \mathrm{CCHCN}\right)$ and methyl triacetylene $\left(\mathrm{CH}_{3} \mathrm{C}_{6} \mathrm{H}\right)$ while methyl cyanoacetylene $\left(\mathrm{CH}_{3} \mathrm{CCCN}\right)$ and methyl cyanodiacetylene $\left(\mathrm{CH}_{3} \mathrm{C}_{5} \mathrm{~N}\right)$ were confirmed. Towards $\mathrm{Sgr} \mathrm{B} 2(\mathrm{~N})$, the three newly detected molecules are cyclopropenone $\left(\mathrm{c}-\mathrm{C}_{3} \mathrm{H}_{2} \mathrm{O}\right)$, ketenimine $\left(\mathrm{CH}_{2} \mathrm{CNH}\right)$, and acetamide $\left(\mathrm{CH}_{3} \mathrm{CONH}_{2}\right)$; these are mainly seen in absorption and are primarily located in an envelope around the hot core. In this work, we report a detailed study of the gas-phase chemistry of all seven molecules.

Methods. Starting with our updated gas-phase chemical reaction network osu.01.2007, we added formation and depletion reactions to treat the chemistry of each of the seven molecules. Some of these were already in our network but with incomplete chemistry, while most were not in the network at all prior to this work. We assumed the standard physical conditions for TMC-1 and assumed that these also hold for the envelope around Sgr B2(N). Standard pseudo-time-dependent calculations were run for each source.

Results. For TMC-1, we reproduced the observed fractional abundances of three detected molecules at early times of $10^{5-6} \mathrm{yr}$ and came close to reproducing a fourth. For the halo surrounding Sgr B2(N), our results are more ambiguous: only for ketenimine were we able to match the observed abundance very well.
\end{abstract}

Key words. ISM: abundances - ISM: molecules - molecular processes

\section{Introduction}

In 2006, detections of seven interstellar molecules with the 100$\mathrm{m}$ Green Bank Telescope (GBT) were reported. Towards the cold core TMC-1, two new molecules - cyanoallene $\left(\mathrm{CH}_{2} \mathrm{CCHCN}\right)$ and methyl triacetylene $\left(\mathrm{CH}_{3} \mathrm{C}_{6} \mathrm{H}\right)$ - were detected and two species - methyl cyanoacetylene $\left(\mathrm{CH}_{3} \mathrm{CCCN}\right)$ and methyl cyanodiacetylene $\left(\mathrm{CH}_{3} \mathrm{C}_{5} \mathrm{~N}\right)$ - confirmed. Towards the hot-core source Sgr B2(N) or, more accurately, its environs, three new molecules were seen: cyclopropenone $\left(\mathrm{c}-\mathrm{C}_{3} \mathrm{H}_{2} \mathrm{O}\right)$, ketenimine $\left(\mathrm{CH}_{2} \mathrm{CNH}\right)$, and acetamide $\left(\mathrm{CH}_{3} \mathrm{CONH}_{2}\right)$. These molecules supplement the earlier detection by Hollis et al. (2004) of propenal and propanal towards Sgr B2(N).

The new molecules detected in TMC-1 are analogous to those previously seen in this exceptional source for unsaturated organic molecules. Lovas et al. (2006a) identified cyanoallene $\left(\mathrm{CH}_{2} \mathrm{CCHCN}\right)$, an isomer of methyl cyanoacetylene $\left(\mathrm{CH}_{3} \mathrm{CCCN}\right)$, and also confirmed the existence of the latter. Cyanoallene was found to be the more abundant species, with a column density of $2 \times 10^{12} \mathrm{~cm}^{-2}$ compared with that of $4.5 \times 10^{11} \mathrm{~cm}^{-2}$ for methyl cyanoacetylene. A similar observation was reported with the use of the 100-m Effelsberg telescope (Chin et al. 2006). The formation mechanism of methyl cyanoacetylene has been discussed by a variety of authors. Schwahn et al. (1986) suggested an ion-molecule synthesis starting with the formation of protonated methyl cyanoacetylene via

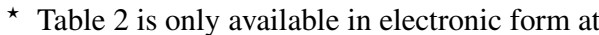
http://www. aanda.org the radiative association of $\mathrm{CH}_{3}^{+}$and cyanoacetylene ( $\left.\mathrm{HCCCN}\right)$ and the subsequent formation of $\mathrm{CH}_{3} \mathrm{CCCN}$ by dissociative recombination with electrons. On the other hand, Balucani et al. (2002) showed that the neutral-radical reactions between $\mathrm{C}_{3} \mathrm{H}_{4}$ in its isomeric forms allene $\left(\mathrm{H}_{2} \mathrm{CCCH}_{2}\right)$ and methyl acetylene $\left(\mathrm{CH}_{3} \mathrm{CCH}\right)$ and the $\mathrm{CN}$ radical react to produce all three isomers of $\mathrm{C}_{4} \mathrm{H}_{3} \mathrm{~N}$ : methyl cyanoacetylene, cyanoallene, and 3-cyano methylacetylene $\left(\mathrm{HCCCH}_{2} \mathrm{CN}\right)$. Although ion-molecule routes to methyl cyanoacetylene are in the two current major networks, RATE06 and osu.01.2007 (http://www.udfa.net/; http://www.physics.ohio-state.edu/ eric/research.html), the neutral-radical synthesis appears to have been omitted. The next member of the methyl cyanopolyyne family $\left(\mathrm{CH}_{3}(\mathrm{CC})_{n} \mathrm{CN}\right)$, methyl cyanodiacetylene $\left(\mathrm{CH}_{3} \mathrm{C}_{5} \mathrm{~N}\right)$, was recently confirmed to be present in TMC-1 with a column density of $7.4 \times 10^{11} \mathrm{~cm}^{-2}$ (Remijan et al. 2006; Snyder et al. 2006); the original detection had been made much earlier (Snyder et al. 1984). This species is present in the two main chemical networks; its synthesis is once again limited to ion-molecule processes. The methyl polyynes $\left(\mathrm{CH}_{3} \mathrm{C}_{2 n} \mathrm{H}\right)$ are another family in TMC-1, and the largest member of this group - methyl triacetylene $\left(\mathrm{CH}_{3} \mathrm{C}_{6} \mathrm{H}\right)$ - has also been detected recently (Remijan et al. 2006) with a column density of $3.1 \times 10^{12} \mathrm{~cm}^{-2}$ although some evidence for this species had been obtained much earlier by Snyder et al. (1984). This species is also in the two networks, where it is produced solely by ion-molecule chemistry. In fact, the computed abundance with an older network of ours, osu.2003, is much too low (Snyder et al. 2006). 
The galactic center source Sgr B2(N) is the site for many discoveries of interstellar molecules, but the three new species reported are of interest in that much of their spectral transitions are in absorption towards the source and two probably derive from a cold halo of material surrounding the hot core or hot cores (Hollis, private communication), as is the case with propenal $\left(\mathrm{CH}_{2} \mathrm{CHCHO}\right)$ and propanal $\left(\mathrm{CH}_{3} \mathrm{CH}_{2} \mathrm{CHO}\right)$ (Hollis et al. 2004). Ketenimine appears to be somewhat of an exception, since it is found closer to the hot core with a rotational temperature of $\approx 65 \mathrm{~K}$. It is unclear what type of model of interstellar chemistry should be applied to these detections, since the material can be thought of as either ambient or affected in some way by the hot core/massive star formation region. The chemistry of none of the three species recently detected towards Sgr $\mathrm{B} 2(\mathrm{~N})$ is in the current major reaction networks.

Ketenimine $\left(\mathrm{CH}_{2} \mathrm{CNH}\right)$ was detected towards $\mathrm{Sgr} \mathrm{B} 2(\mathrm{~N})$ with a column density of $1.5 \times 10^{16} \mathrm{~cm}^{-2}$ by Lovas et al. (2006b), corresponding to a fractional abundance of $(0.1-3.0) \times 10^{-9}$ with respect to $\mathrm{H}_{2}$. They suggested that this molecule is likely formed by isomerization of methyl cyanide $\left(\mathrm{CH}_{3} \mathrm{CN}\right)$ with energy supplied by shocks. Cyclopropenone $\left(\mathrm{c}-\mathrm{C}_{3} \mathrm{H}_{2} \mathrm{O}\right)$ was detected towards this source by Hollis et al. (2006a) with a column density of $\approx 1 \times 10^{13} \mathrm{~cm}^{-2}$, corresponding to a fractional abundance with respect to $\mathrm{H}_{2}$ of $\approx 6 \times 10^{-11}$. Hollis et al. (2006a) maintained that since c- $\mathrm{C}_{3} \mathrm{H}_{2}$ is also present, it is possible that cyclopropenone can be formed from the simpler ring species by some type of oxygen addition. Finally, Hollis et al. (2006b) found another molecule, acetamide $\left(\mathrm{CH}_{3} \mathrm{CONH}_{2}\right)$, towards the environs of $\mathrm{Sgr}$ B2(N) with a column density of $1.8 \times 10^{14} \mathrm{~cm}^{-2}$. They wrote that the exothermic reaction of formamide $\left(\mathrm{HCONH}_{2}\right)$ with the methylene radical $\left(\mathrm{CH}_{2}\right)$ could account for the synthesis of interstellar acetamide in the presence of shock phenomena, although radiative association reactions normally are fastest under lowenergy conditions.

In this paper, we report a detailed look at the chemistry of these seven species undertaken to determine if they can be produced by gas-phase processes under ambient and quiescent cold cloud conditions. Although such conditions likely pertain to TMC-1, it is not clear that they do indeed pertain to even the colder portions of the envelope of Sgr B2(N). For the TMC-1 species, we incorporate some neutral-radical reactions to enhance the rate of formation of the species considered, of which three-quarters are already in our osu.01.2007 network, while for the Sgr B2(N) species, we must include these three molecules in our network for the first time. We do not include the molecules detected by Hollis et al. (2004) towards Sgr B2(N) propenal $\left(\mathrm{CH}_{2} \mathrm{CHCHO}\right)$ and propanal $\left(\mathrm{CH}_{3} \mathrm{CH}_{2} \mathrm{CHO}\right)$ - because these, especially the latter, bear the characteristics of saturated or nearly-saturated species formed on grain surfaces.

The remainder of the paper is divided as follows. In Sect. 2, we briefly describe the chemical reaction network used, and then discuss the adopted chemistry of each of the seven molecules. In Sect. 3, we present our modeling results and compare them with observational abundances. Section 4 contains our conclusions.

\section{Molecules and synthesis}

We started with the latest version of the gas-phase chemical reaction network, osu.01.2007, which contains 452 species and 4431 reactions (http://www.physics.ohio-state.edu/ eric/ research.html). A molecular hydrogen density $n_{\mathrm{H}}=2 \times$ $10^{4} \mathrm{~cm}^{-3}$, a temperature $T=10 \mathrm{~K}$, a cosmic-ray ionization rate $\zeta=1.3 \times 10^{-17} \mathrm{~s}^{-1}$, and a visual extinction $A_{\mathrm{V}}=10 \mathrm{mag}$ were used for both TMC-1 and the cold halo around Sgr B2(N).
Table 1. Initial abundances.

\begin{tabular}{lll}
\hline \hline Species & Sgr B2(N) & TMC-1 \\
\hline $\mathrm{He}$ & $6.00 \times 10^{-2}$ & $6.00 \times 10^{-2}$ \\
$\mathrm{~N}$ & $2.14 \times 10^{-5}$ & $2.14 \times 10^{-5}$ \\
$\mathrm{O}$ & $1.76 \times 10^{-4}$ & $6.10 \times 10^{-5}$ \\
$\mathrm{H}_{2}$ & $5.00 \times 10^{-1}$ & $5.00 \times 10^{-1}$ \\
$\mathrm{C}^{+}$ & $7.30 \times 10^{-5}$ & $7.30 \times 10^{-5}$ \\
$\mathrm{~S}^{+}$ & $8.00 \times 10^{-8}$ & $8.00 \times 10^{-8}$ \\
$\mathrm{Si}^{+}$ & $8.00 \times 10^{-9}$ & $8.00 \times 10^{-9}$ \\
$\mathrm{Fe}^{+}$ & $3.00 \times 10^{-9}$ & $3.00 \times 10^{-9}$ \\
$\mathrm{Na}^{+}$ & $2.00 \times 10^{-9}$ & $2.00 \times 10^{-9}$ \\
$\mathrm{Mg}^{+}$ & $7.00 \times 10^{-9}$ & $7.00 \times 10^{-9}$ \\
$\mathrm{P}^{+}$ & $3.00 \times 10^{-9}$ & $3.00 \times 10^{-9}$ \\
$\mathrm{Cl}^{+}$ & $4.00 \times 10^{-9}$ & $4.00 \times 10^{-9}$ \\
$\mathrm{~F}^{+}$ & $6.69 \times 10^{-9}$ & $6.69 \times 10^{-9}$ \\
$\mathrm{e}^{-}$ & $7.31 \times 10^{-5}$ & $7.31 \times 10^{-5}$ \\
\hline
\end{tabular}

For the warmer region where ketenimine is detected we raised the temperature to $50 \mathrm{~K}$. For $\operatorname{Sgr} \mathrm{B} 2(\mathrm{~N})$, we used the standard low-metal elemental abundances (Graedel et. al 1982) while for TMC-1 we used carbon-rich elemental abundances (Wakelam et al. 2006). The initial abundances for both cases are listed in Table 1 with respect to the total hydrogen nuclei $n_{\mathrm{H}}$. Reactions added to our network to treat the chemistry of the GBT molecules are listed in Table 2 (online only) along with their adopted rate coefficients $k$ and references. This table also contains current reactions in the network pertaining to these species. For bimolecular reactions, the rate coefficients are parameterized by the expression $k=\alpha \times(T / 300)^{\beta} \times \exp [-\gamma / T]$, whereas for cosmic-ray induced photodissociation, $k=\alpha \times \zeta$.

\subsection{Molecules detected in TMC-1}

To compute abundances for methyl cyanoacetylene and cyanoallene, we included their formation by neutral-radical reactions involving the radical $\mathrm{CN}$ and the hydrocarbons methyl acetylene $\left(\mathrm{CH}_{3} \mathrm{CCH}\right)$ and allene $\left(\mathrm{CH}_{2} \mathrm{CCH}_{2}\right)$. The former is a well-known interstellar molecule, while allene cannot be detected since it is nonpolar. These hydrocarbon isomers are not treated individually in our network; instead, we consider the sum of their abundances, labeled as a species $\mathrm{C}_{3} \mathrm{H}_{4}$, and add a parameter $\delta=$ $\left[\mathrm{CH}_{3} \mathrm{CCH}\right] /\left[\mathrm{C}_{3} \mathrm{H}_{4}\right]$, which can be varied, for use in the chemical reaction network. The neutral-radical reactions have been studied via the CRESU technique (Carty et al. 2001) and found to have temperature-independent rate coefficients in the range $15-295 \mathrm{~K}$ of $4.1 \times 10^{-10} \mathrm{~cm}^{3} \mathrm{~s}^{-1}$. A subsequent combined crossbeam and ab initio study (Balucani et al. 2002) found the products for these two reactions shown below:

$$
\begin{aligned}
& \mathrm{CH}_{3} \mathrm{CCH}+\mathrm{CN} \rightarrow \mathrm{CH}_{2} \mathrm{CCHCN}+\mathrm{H} \\
& \mathrm{CH}_{3} \mathrm{CCH}+\mathrm{CN} \rightarrow \mathrm{CH}_{3} \mathrm{CCCN}+\mathrm{H} \\
& \mathrm{CH}_{2} \mathrm{CCH}_{2}+\mathrm{CN} \rightarrow \mathrm{CH}_{2} \mathrm{CCHCN}+\mathrm{H} \\
& \mathrm{CH}_{2} \mathrm{CCH}_{2}+\mathrm{CN} \rightarrow \mathrm{HCCCH}_{2} \mathrm{CN}+\mathrm{H}
\end{aligned}
$$

where the product ratio between cyanoallene and methyl cyanoacetylene in reactions (1) and (2) is 1:1 and that between cyanoallene and the third isomer, 3-cyano methylacetylene $\left(\mathrm{HCCCH}_{2} \mathrm{CN}\right)$, in reactions (3) and (4) is 9:1. This third isomer has not yet been detected in the interstellar medium, possibly because 3-cyano methylacetylene $\left(\mathrm{HCCCH}_{2} \mathrm{CN}\right)$ has a much smaller dipole moment than the other two isomers. If we label 
the reaction rate coefficient for reactions $\mathrm{C}_{3} \mathrm{H}_{4}+\mathrm{CN} \rightarrow \mathrm{C}_{4} \mathrm{H}_{3} \mathrm{~N}$ $+\mathrm{H}$ to be $k$, the production rate of cyanoallene is $[0.5 \times \delta+0.9 \times$ $(1-\delta)] \times k$, while those for methyl cyanoacetylene and 3-cyano methylacetylene are $[0.5 \times \delta] \times k$ and $[0.1 \times(1-\delta)] \times k$ respectively.

In addition to the neutral-radical channels, the three isomers can be formed from ion-molecule channels, which lead initially to the production of a protonated ion precursor, $\mathrm{C}_{4} \mathrm{H}_{4} \mathrm{~N}^{+}$. Although the structural isomers of this ion are not known, to the best of our knowledge, we assume that when they undergo dissociative recombination leading to channels that form the three $\mathrm{C}_{4} \mathrm{H}_{3} \mathrm{~N}$ isomers:

$$
\begin{aligned}
& \mathrm{C}_{4} \mathrm{H}_{4} \mathrm{~N}^{+}+\mathrm{e}^{-} \rightarrow \mathrm{CH}_{2} \mathrm{CCHCN}+\mathrm{H} \\
& \mathrm{C}_{4} \mathrm{H}_{4} \mathrm{~N}^{+}+\mathrm{e}^{-} \rightarrow \mathrm{CH}_{3} \mathrm{CCCN}+\mathrm{H} \\
& \mathrm{C}_{4} \mathrm{H}_{4} \mathrm{~N}^{+}+\mathrm{e}^{-} \rightarrow \mathrm{HCCCH}_{2} \mathrm{CN}+\mathrm{H},
\end{aligned}
$$

the relative rates of production of the isomers are the same as for the neutral-radical pathways. The argument is based on the assumption that the isomers of the ion are related in an intimate manner to those of the $\mathrm{C}_{4} \mathrm{H}_{3} \mathrm{~N}$ isomers. Our calculations show that the neutral-radical channels are the more important. It should be noted that for all dissociative recombination reactions considered in this paper, branching fractions in which more than one $\mathrm{H}$ atom is removed are also included. After being produced, the neutral $\mathrm{C}_{4} \mathrm{H}_{3} \mathrm{~N}$ molecules are destroyed via standard ion-molecule reactions with ions such as $\mathrm{HCO}^{+}, \mathrm{H}_{3}^{+}, \mathrm{C}^{+}$ and $\mathrm{He}^{+}$, as well as via photodissociation caused by cosmic-ray induced photons. Some of the ion-molecule reactions protonate the $\mathrm{C}_{4} \mathrm{H}_{3} \mathrm{~N}$ species, which are reformed via dissociative recombination reactions with less than $100 \%$ efficiency since there are other product channels.

In the current network, methyl cyanodiacetylene $\left(\mathrm{CH}_{3} \mathrm{C}_{5} \mathrm{~N}\right)$ is produced in one channel of the dissociative recombination of $\mathrm{C}_{6} \mathrm{H}_{4} \mathrm{~N}^{+}$:

$\mathrm{C}_{6} \mathrm{H}_{4} \mathrm{~N}^{+}+\mathrm{e}^{-} \rightarrow \mathrm{CH}_{3} \mathrm{C}_{5} \mathrm{~N}+\mathrm{H}$.

To supplement its formation rate, we have added the neutralradical reaction

$\mathrm{CN}+\mathrm{CH}_{3} \mathrm{C}_{4} \mathrm{H} \rightarrow \mathrm{CH}_{3} \mathrm{C}_{5} \mathrm{~N}+\mathrm{H}$,

in analogy with the measured formation of methyl cyanoacetylene (Carty et al. 2001). For the rate coefficient of this reaction, we chose the same parameters as measured for $\mathrm{CN}+\mathrm{CH}_{3} \mathrm{CCH}$ (Carty et al. 2001). Once produced, methyl cyanodiacetylene is destroyed by ion-molecule reactions and cosmic ray-induced photodissociation.

For the final GBT molecule observed in TMC-1, methyl triacetylene $\left(\mathrm{CH}_{3} \mathrm{C}_{6} \mathrm{H}\right)$, the current network contains only the synthesis via the dissociative recombination of the precursor ion $\mathrm{C}_{7} \mathrm{H}_{5}^{+}$:

$\mathrm{C}_{7} \mathrm{H}_{5}^{+}+\mathrm{e}^{-} \rightarrow \mathrm{CH}_{3} \mathrm{C}_{6} \mathrm{H}+\mathrm{H}$.

To this reaction, we have added the following neutral-radical reactions:

$$
\begin{aligned}
& \mathrm{CCH}+\mathrm{CH}_{3} \mathrm{C}_{4} \mathrm{H} \rightarrow \mathrm{CH}_{3} \mathrm{C}_{6} \mathrm{H}+\mathrm{H} \\
& \mathrm{C}_{6} \mathrm{H}+\mathrm{CH}_{4} \rightarrow \mathrm{CH}_{3} \mathrm{C}_{6} \mathrm{H}+\mathrm{H} .
\end{aligned}
$$

The reaction involving the $\mathrm{CCH}$ radical is assumed to proceed at the same rate as the reaction between $\mathrm{CCH}$ and $\mathrm{CH}_{3} \mathrm{CCH}$, which has been studied in the laboratory by Carty et al. (2001). This reaction has also been added to the network. The reaction between $\mathrm{C}_{6} \mathrm{H}$ and $\mathrm{CH}_{4}$ is based on one between $\mathrm{CCH}$ and $\mathrm{CH}_{4}$, which has only been studied at $300 \mathrm{~K}$ (Laufer \& Fahr 2004), and has a rate somewhat below the standard neutral-radical value, possibly suggesting a small activation energy barrier. We assume here nevertheless that its rate coefficient is independent of temperature. In our calculations, the reaction is at least as important in the production of methyl triacetylene as that involving $\mathrm{CCH}$. Once produced, methyl triacetylene is depleted by ion-molecule reactions, reaction with atomic carbon, and cosmic-ray-induced photodissociation.

\subsection{Sgr B2 molecules}

Ketenimine $\left(\mathrm{CH}_{2} \mathrm{CNH}\right)$ is likely formed by the dissociative recombination of protonated acetonitrile, $\mathrm{CH}_{3} \mathrm{CNH}^{+}$, which also serves as a precursor for acetonitrile $\left(\mathrm{CH}_{3} \mathrm{CN}\right)$ and the cyanomethyl radical:

$$
\begin{aligned}
& \mathrm{CH}_{3} \mathrm{CNH}^{+}+\mathrm{e}^{-} \rightarrow \mathrm{CH}_{2} \mathrm{CNH}+\mathrm{H} \\
& \mathrm{CH}_{3} \mathrm{CNH}^{+}+\mathrm{e}^{-} \rightarrow \mathrm{CH}_{3} \mathrm{CN}+\mathrm{H} \\
& \mathrm{CH}_{3} \mathrm{CNH}^{+}+\mathrm{e}^{-} \rightarrow \mathrm{CH}_{2} \mathrm{CN}+\mathrm{H}+\mathrm{H}
\end{aligned}
$$

We assume that each channel is produced equally. If our assumption is correct, ketenimine should also be detectable in TMC-1 along with acetonitrile and cyanomethyl, since these species are detected there. Once produced, the ketenimine molecules can be destroyed by reactions with relatively abundant ions.

Deducing a reaction pathway for the formation of cyclopropenone $\left(\mathrm{c}-\mathrm{C}_{3} \mathrm{H}_{2} \mathrm{O}\right)$ is less simple (Hollis et al. 2006a). Since the related species $\mathrm{c}-\mathrm{C}_{3} \mathrm{H}_{2}$ is ubiquitous in the interstellar medium, it is natural to determine whether it can be a precursor to cyclopropenone through some reaction with an oxygencontaining species. Let us first consider the following neutralneutral reactions:

$\mathrm{c}-\mathrm{C}_{3} \mathrm{H}_{2}+\mathrm{O}_{2} \rightarrow \mathrm{c}-\mathrm{C}_{3} \mathrm{H}_{2} \mathrm{O}+\mathrm{O}$,

$\mathrm{c}-\mathrm{C}_{3} \mathrm{H}_{2}+\mathrm{O} \rightarrow \mathrm{c}-\mathrm{C}_{3} \mathrm{H}_{2} \mathrm{O}+\mathrm{h} v$

$\mathrm{c}-\mathrm{C}_{3} \mathrm{H}_{2}+\mathrm{OH} \rightarrow \mathrm{c}-\mathrm{C}_{3} \mathrm{H}_{2} \mathrm{O}+\mathrm{H}$.

Of these three reactions, however, only that with the radical $\mathrm{OH}$ does not possess a barrier according to quantum chemical calculations (Talbi, private communication). What about ion-molecule pathways leading to the protonated precursor c- $\mathrm{C}_{3} \mathrm{H}_{3} \mathrm{O}^{+}$, which can then undergo dissociative recombination to form cyclopropenone:

c- $\mathrm{C}_{3} \mathrm{H}_{3} \mathrm{O}^{+}+\mathrm{e}^{-} \rightarrow \mathrm{c}-\mathrm{C}_{3} \mathrm{H}_{2} \mathrm{O}+\mathrm{H}$ ?

The $\mathrm{c}-\mathrm{C}_{3} \mathrm{H}_{3} \mathrm{O}^{+}$might be produced by various ion-neutral reactions between ions with a three-carbon cylic structure and oxygen-containing molecules/atoms such as:

$\mathrm{c}-\mathrm{C}_{3} \mathrm{H}_{2}^{+}+\mathrm{H}_{2} \mathrm{O} \rightarrow \mathrm{c}-\mathrm{C}_{3} \mathrm{H}_{3} \mathrm{O}^{+}+\mathrm{H}$
$\mathrm{c}-\mathrm{C}_{3} \mathrm{H}_{3}^{+}+\mathrm{O} \rightarrow \mathrm{c}-\mathrm{C}_{3} \mathrm{H}_{2} \mathrm{O}^{+}+\mathrm{H}$
$\mathrm{c}-\mathrm{C}_{3} \mathrm{H}_{2} \mathrm{O}^{+}+\mathrm{H}_{2} \rightarrow \mathrm{c}-\mathrm{C}_{3} \mathrm{H}_{3} \mathrm{O}^{+}+\mathrm{H}$

c- $\mathrm{C}_{3} \mathrm{H}_{4}^{+}+\mathrm{O} \rightarrow \mathrm{c}-\mathrm{C}_{3} \mathrm{H}_{3} \mathrm{O}^{+}+\mathrm{H}$. 
The first reaction of the four has been found not to occur at room temperature in the laboratory (Prodnuk et al. 1992), while the two step-synthesis starting from reaction (21) fails because the subsequent hydrogenation reaction is endothermic. Only reaction (23) remains a possible pathway to form protonated cyclopropenone starting from a three-membered ring, and this reaction has been added to our network. In addition, if the radiative association between $\mathrm{C}_{2} \mathrm{H}_{3}^{+}$and $\mathrm{CO}$ to form an ion of the generic formula $\mathrm{C}_{3} \mathrm{H}_{3} \mathrm{O}^{+}$, which is already in our network, produces a ring, protonated cyclopropenone is the result:

$\mathrm{C}_{2} \mathrm{H}_{3}^{+}+\mathrm{CO} \rightarrow \mathrm{c}-\mathrm{C}_{3} \mathrm{H}_{3} \mathrm{O}^{+}+\mathrm{h} v$.

The association reaction has, however, been studied in the threebody limit by Scott et al. (1995), who found the dominant product to be protonated propadienone $\left(\mathrm{H}_{2} \mathrm{CCHCO}^{+}\right)$. These authors used their results to rule out reaction (24) as a source of protonated propynal, which would then lead to propynal, a known interstellar molecule actually detected towards Sgr B2(N) (Hollis et al. 2004). Cyclopropenone is destroyed by reactions with ions.

For the third detected molecule in the halo surrounding $\mathrm{Sgr}$ B2 $(\mathrm{N})$, acetamide $\left(\mathrm{CH}_{3} \mathrm{CONH}_{2}\right)$, Hollis et al. (2006b) suggested the main formation method might be the exothermic neutralradical reaction between formamide and the methylene $\left(\mathrm{CH}_{2}\right)$ radical:

$$
\mathrm{NH}_{2} \mathrm{CHO}+\mathrm{CH}_{2} \rightarrow \mathrm{CH}_{3} \mathrm{CONH}_{2}+\mathrm{h} v \text {. }
$$

This reaction, however, involves a spin flip and thus probably an energy barrier. In addition, it is an association reaction, which must occur via radiative stabilization in the low-density interstellar medium. A more likely radiative association reaction involving formamide is the ion-molecule system

$$
\mathrm{NH}_{2} \mathrm{CHO}+\mathrm{CH}_{3}^{+} \rightarrow \mathrm{CH}_{3} \mathrm{CHONH}_{2}^{+}+\mathrm{h} v \text {, }
$$

which produces protonated acetamide. This species can then form acetamide by dissociative recombination:

$$
\mathrm{CH}_{3} \mathrm{CHONH}_{2}^{+}+\mathrm{e}^{-} \rightarrow \mathrm{CH}_{3} \mathrm{CONH}_{2}+\mathrm{H} \text {. }
$$

Because the rate coefficient for reaction (26) has not been calculated or measured, we assume that it possesses the large value of $1 \times 10^{-9} \mathrm{~cm}^{3} \mathrm{~s}^{-1}$ at $10 \mathrm{~K}$. We also consider a second radiative association reaction, involving acetaldehyde $\left(\mathrm{CH}_{3} \mathrm{CHO}\right)$ and the ammonium ion:

$$
\mathrm{CH}_{3} \mathrm{CHO}+\mathrm{NH}_{4}^{+} \rightarrow \mathrm{CH}_{3} \mathrm{CHONH}_{4}^{+}+\mathrm{h} v,
$$

which produces a large positive ion. This ion can, among other channels, produce acetamide upon dissociative recombination with electrons. Once again, we assume that the rate coefficient for this radiative association is large at $10 \mathrm{~K}$. These and other radiative association reactions considered in this paper may well form product isomers not included here. If the reactions are found to be efficient in producing the desired species, then detailed calculations and or experiments will have to be undertaken to determine the actual rates and products formed. Acetamide is depleted by ion-molecule reactions.

\section{Results and discussion}

\section{1. $T M C-1$}

Figure 1 shows calculated fractional abundances with respect to $\mathrm{H}_{2}$ for the two observed isomers of $\mathrm{C}_{4} \mathrm{H}_{3} \mathrm{~N}$, methyl cyanoacetylene and cyanoallene, near their peak early-time values
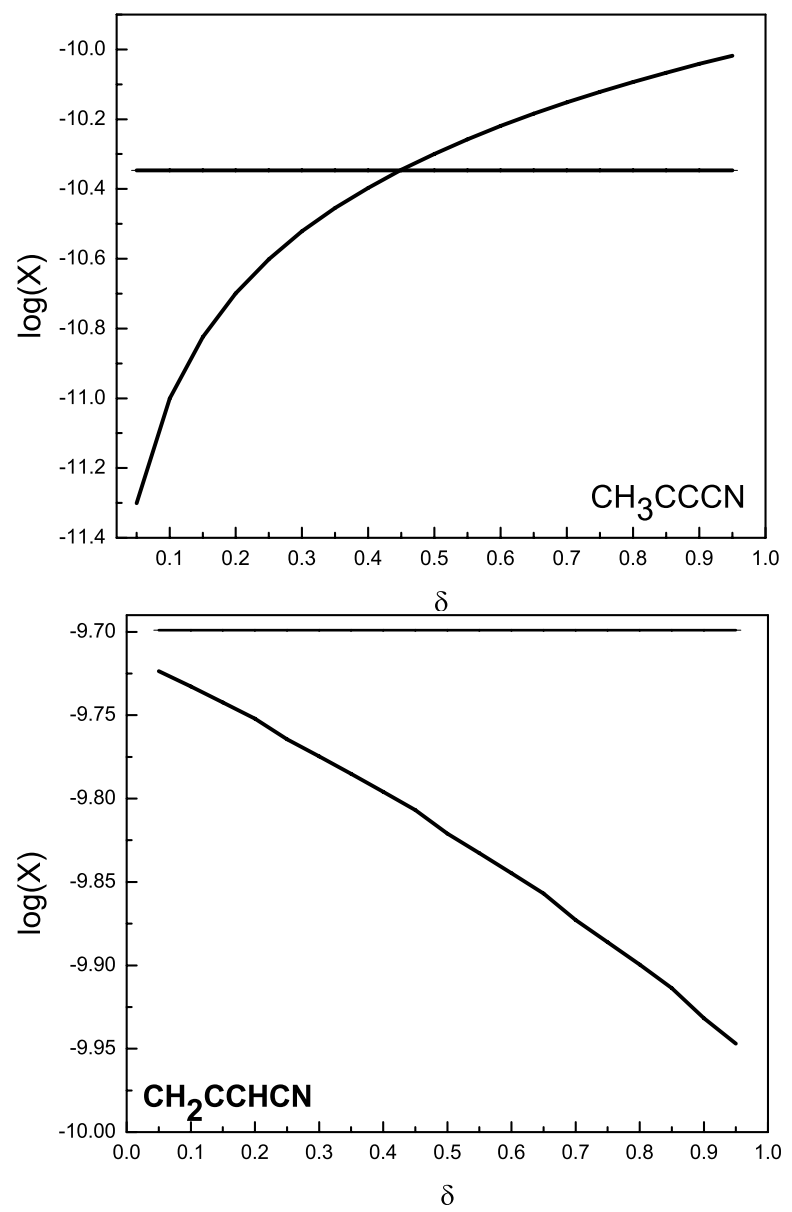

Fig. 1. Calculated fractional abundances $X$ (with respect to $\mathrm{H}_{2}$ ) at $1 \times$ $10^{5} \mathrm{yr}$ plotted vs. the parameter $\delta$ (see text); upper panel, $\mathrm{CH}_{3} \mathrm{CCCN}$; lower panel, $\mathrm{CH}_{2} \mathrm{CCHCN}$. Observed values shown as horizontal lines.

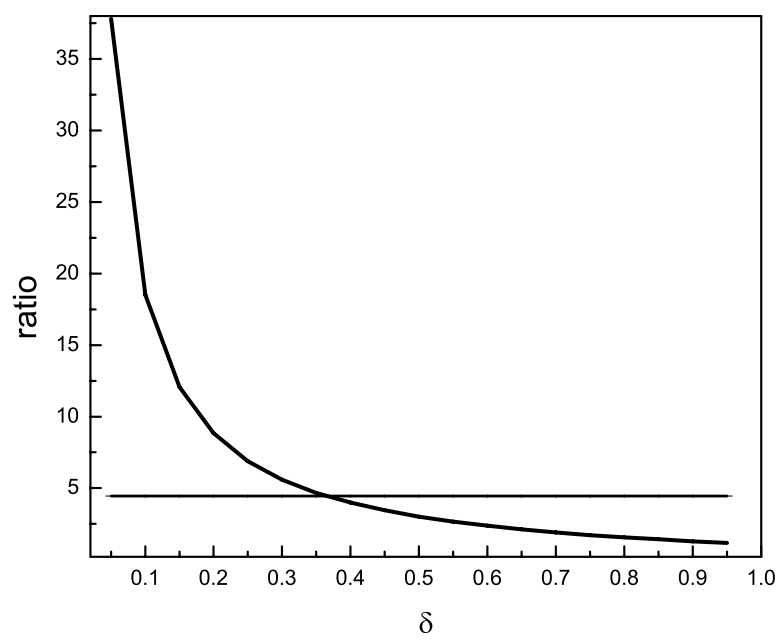

Fig. 2. Calculated abundance ratio of cyanoallene to methyl cyanoacetylene at $t=1 \times 10^{5} \mathrm{yr}$ plotted vs. parameter $\delta$. Observed ratio of 4.5 plotted as horizontal line.

( $t=1 \times 10^{5} \mathrm{yr}$ ) as a function of the parameter $\delta$, which is the ratio of the abundance of methyl acetylene to the sum of the methyl acetylene and allene abundances. Also shown are the observed fractional abundances with respect to $\mathrm{H}_{2}$ for methyl cyanoacetylene and cyanoallene, based on the column density results of Lovas et al. (2006a) and the assumption that the $\mathrm{H}_{2}$ column density is $10^{22} \mathrm{~cm}^{-2}$. It can be seen that at early-time the calculated 

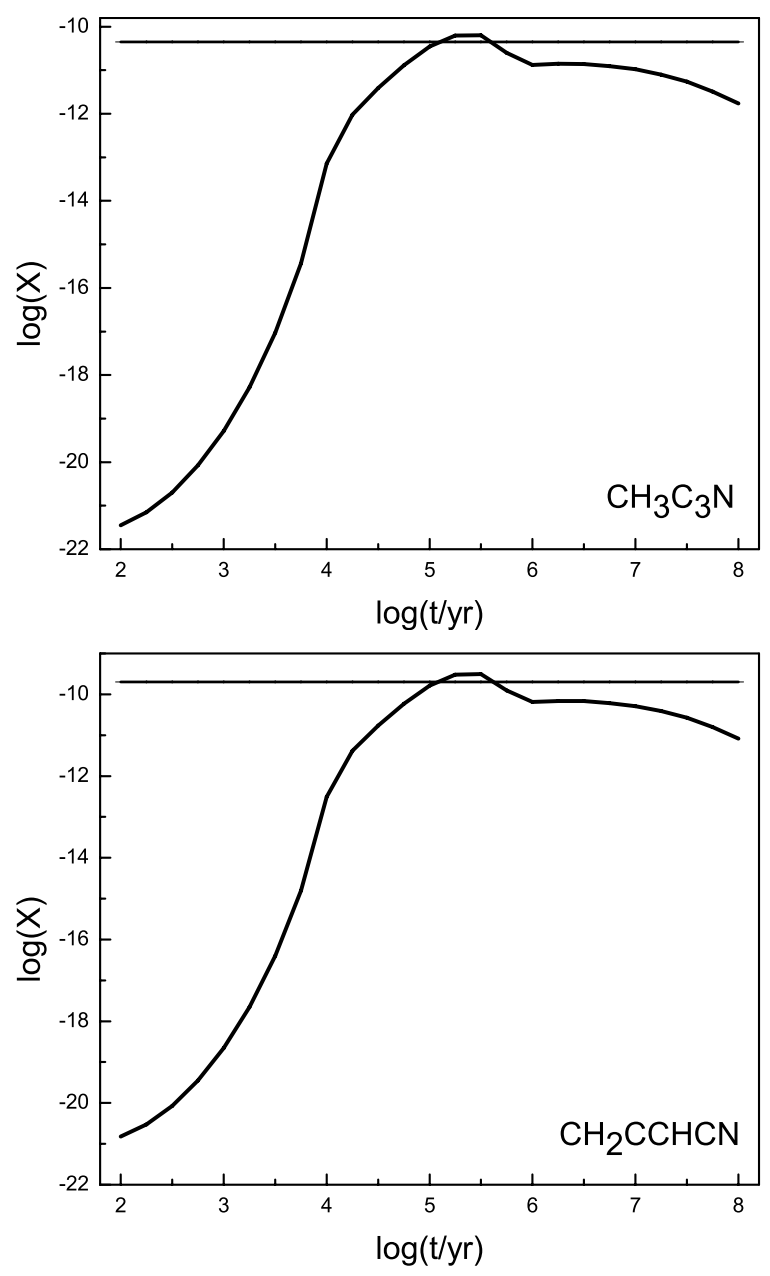

Fig. 3. Calculated fractional abundances of $\mathrm{C}_{4} \mathrm{H}_{3} \mathrm{~N}$ isomers vs. time; upper panel, methyl cyanoacetylene $\left(\mathrm{CH}_{3} \mathrm{CCCN}\right)$; lower panel, cyanoallene $\left(\mathrm{CH}_{2} \mathrm{CCHCN}\right) ; \delta=0.35$. Observed abundances shown as horizontal lines.

abundance of cyanoallene is in reasonable agreement with observation for all values of $\delta$. The worst agreement occurs as $\delta$ approaches unity, but even here the calculated abundance is low by a factor less than two. The role of $\delta$ is more important for the calculation of the methyl cyanoacetylene abundance; here the calculated abundance is almost an order of magnitude low when $\delta$ is near zero but increases rapidly with increasing $\delta$. This result is reasonable because, as discussed previously, methyl acetylene is the main source of methyl cyanoacetylene. To obtain some sort of fit for the best value of $\delta$, we can look at the calculated abundance ratio between cyanoallene and methyl acetylene at early-time, the observed value of which is 4.5. Figure 2 shows the calculated ratio plotted against $\delta$; it can be seen that a value of 0.35 gives the best agreement with observation. Thus, we predict that the abundance of methyl acetylene is 0.35 and that of allene 0.65 of the overall $\mathrm{C}_{3} \mathrm{H}_{4}$ abundance. Or, put differently, the abundance of allene is almost double that of methyl acetylene.

With $\delta=0.35$, we plot the calculated methyl cyanoacetylene and cyanoallene fractional abundances against time in Fig. 3. The similarity between the two figures stems from the fact that the molecules are produced from $\mathrm{C}_{3} \mathrm{H}_{4}$ isomers with a constant abundance ratio and destroyed in a similar fashion. It can be seen that the values peak at times slightly greater than $10^{5} \mathrm{yr}$ but are
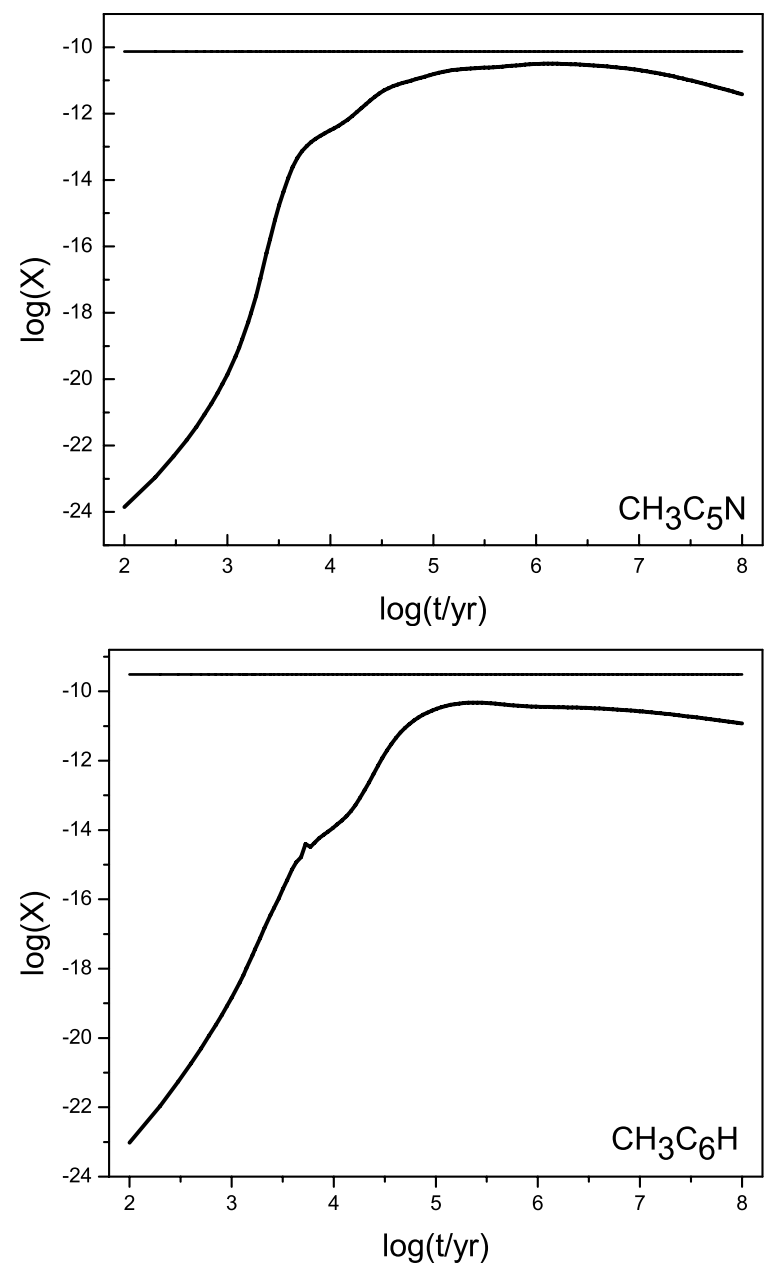

Fig. 4. Calculated fractional abundances of methyl cyanodiacetylene $\left(\mathrm{CH}_{3} \mathrm{C}_{5} \mathrm{~N}\right)$ and methyl triacetylene $\left(\mathrm{CH}_{3} \mathrm{C}_{6} \mathrm{H}\right)$ plotted vs. time. Horizontal lines represent observed abundances.

in excellent agreement with observation from $10^{5} \mathrm{yr}$ through $10^{7} \mathrm{yr}$. Furthermore, the predicted abundance of the third isomer, 3-cyanomethylacetylene $\left(\mathrm{HCCCH}_{2} \mathrm{CN}\right)$, is $\approx 1 \times 10^{-11}$ at early time, a value lower than those for methyl cyanoacetylene and cyanoallene by factors of $\approx 4$ and $\approx 16$, respectively.

The calculated fractional abundances of methyl cyanodiacetylene and methyl triacetylene are shown in Figure 4 as functions of time. Also plotted as horizontal lines are the observed fractional abundances of $\approx 8 \times 10^{-11}$ for methyl cyanodiacetylene (Snyder et al. 2006; Remijan et al. 2006) and $3 \times 10^{-10}$ for methyl triacetylene (Remijan et al. 2006). As can be seen in the figure, the calculated abundance for methyl cyanodiacetylene is now in excellent agreement with observation from times starting at $10^{5} \mathrm{yr}$. The synthesis involving the reaction between $\mathrm{CN}$ and $\mathrm{CH}_{3} \mathrm{C}_{4} \mathrm{H}$ is thus quite superior to the ion-molecule pathways, found totally inadequate by Snyder et al. (2006). The calculated abundance for methyl triacetylene is, however, in poorer agreement with the observation; values obtained at $\geq 2 \times 10^{5} \mathrm{yr}$ are almost one order of magnitude too low. Nevertheless, the combined uncertainties in observed and calculated values will result in an overlap of Gaussian distributions if one assumes an observational uncertainty of a factor of three (up or down) and calculated uncertainties similar to those found for TMC-1 by Wakelam et al. (2006). 


\subsection{Halo of Sgr B2 (N)}

Figure 5 shows the calculated fractional abundance of ketenimine $\left(\mathrm{CH}_{2} \mathrm{CNH}\right)$ as a function of time as well as a gray area that depicts the range of observed abundances. The assumed temperature has been raised to $50 \mathrm{~K}$ from the $10 \mathrm{~K}$ appropriate to the cold halo, and the result is an increase of a factor of three in the peak calculated abundance. The early-time abundance at either temperature is well within the observed range, and so it appears that a standard gas-phase analysis at low temperature reproduces observation. Naturally, the calculated result is based solely on whether or not the dissociative recombination reaction between protonated acetonitrile and electrons has a significant channel that leads to $\mathrm{CH}_{2} \mathrm{CNH}+\mathrm{H}$. Note that since oxygen-rich abundances are used, there is a sharp drop-off past early time for organic molecules such as ketenimine.

In complete contrast to the case of ketenimine, the cold gas-phase model fails for the case of acetamide $\left(\mathrm{CH}_{3} \mathrm{CONH}_{2}\right)$. Compared with the observed fractional abundance of $1.1 \times 10^{-9}$ (Hollis et al. 2006b), our peak calculated value is about six orders of magnitude too low. The huge discrepancy derives from the fact that our starting materials, formamide and acetaldehyde, themselves have small abundances. We attempted to boost the abundance of formamide $\left(\mathrm{NH}_{2} \mathrm{CHO}\right)$ by including a possible radiative association reaction between $\mathrm{NH}_{4}^{+}$and $\mathrm{H}_{2} \mathrm{CO}$ :

$\mathrm{NH}_{4}^{+}+\mathrm{H}_{2} \mathrm{CO} \rightarrow \mathrm{NH}_{4} \mathrm{CH}_{2} \mathrm{O}^{+}+\mathrm{h} \nu$

followed by dissociative recombination. The association reaction is known to occur under high-density conditions (Adams et al. 1980), but even with the assumption that the radiative association reaction has a very large rate coefficient, we do not produce much more formamide than without the reaction. If the problem lies in our underproduction of formamide, we can reexpress the calculated abundance of acetamide in terms of that of formamide; at early time our predicted abundance ratio is 0.003 . The observed abundance ratio in the cold halo region is $0.1-0.5$ (Hollis et al. 2006b). So, it would appear that formamide is not the proper precursor in any event.

Finally, the case of cyclopropenone is somewhat ambiguous. If one assumes that the radiative association reaction between $\mathrm{C}_{2} \mathrm{H}_{3}^{+}$and $\mathrm{CO}$ (Scott et al. 1995) does lead to protonated cyclopropenone, then a peak fractional abundance exceeding $10^{-10}$ for cyclopropenone is computed for early-time. This abundance compares favorably with the observed value of $6 \times 10^{-11}$ (Hollis et al. 2006a). However, it is more likely that the dominant product of the radiative association is not the ring-closure product but instead protonated propadienone, so that the production rate of cyclopropenone via this route is at best $\approx 1-5 \%$ of the production rate of propadienone, which has not yet been detected in the interstellar medium (McEwan, private communication). In that case, the peak calculated fractional abundance lies well below the observed value. If we rule out the association reaction (reaction 24), there remain two other pathways: the neutral-radical reaction involving $\mathrm{c}-\mathrm{C}_{3} \mathrm{H}_{2}$ and $\mathrm{OH}$ and the ion-molecule reaction between $\mathrm{C}_{3} \mathrm{H}_{4}^{+}$and $\mathrm{O}$. Given the low abundance of the $\mathrm{C}_{3} \mathrm{H}_{4}^{+}$ion, the neutral-radical channel dominates but only leads to the production of a fractional abundance for cyclopropenone at earlytime of $6 \times 10^{-12}$, which is an order of magnitude low. Given the difficulty of deducing the proper $\mathrm{H}_{2}$ column density in this source as well as the uncertainty in the calculated abundance (Wakelam et al. 2006), the cold gas-phase production mechanism cannot be ruled out.

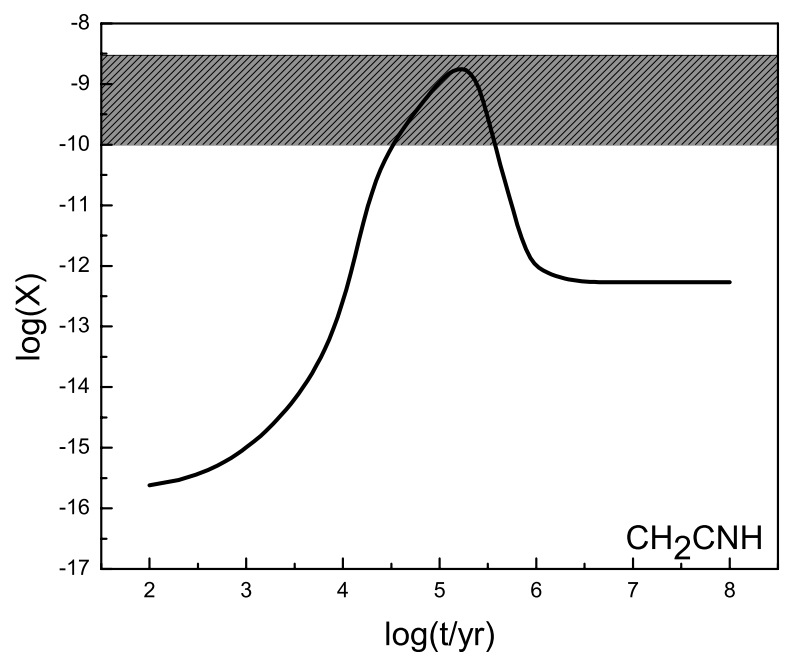

Fig. 5. Calculated fractional abundance of ketenimine plotted as a function of time. The shadowed region represents the range of observed values. The assumed temperature is $50 \mathrm{~K}$.

\section{Conclusions}

Sgr B2(N) is a complex source with a core-halo type structure, from which organic molecules can be detected in absorption. Although such molecules may currently be existing under the cold conditions of the halo, it is certainly not clear where their origin was. Nevertheless, Occam's Razor suggests that one make the simplest assumption as an initial guess: the molecules are produced by gas-phase processes in the outer regions where they are detected. Only if this assumption fails should one go to more complex hypotheses. Unlike the case for the cold dark cloud core TMC-1, where the gas-phase model works tolerably well for those molecules either newly-detected or confirmed by the use of the GBT, the gas-phase model performs rather poorly for two of the the three new molecules detected towards Sgr B2(N). If one adds to this score the failure of gas-phase models to reproduce earlier observed abundances of propenal $\left(\mathrm{CH}_{2} \mathrm{CHCHO}\right)$ and propanal $\left(\mathrm{CH}_{3} \mathrm{CH}_{2} \mathrm{CHO}\right)$ towards the same source (Hollis et al. 2004), one comes to the conclusion that most organic species towards Sgr B2(N) are formed at least partially on granular surfaces.

This assumption raises new problems; in particular, how do the molecules leave the grains in a cold region? One possibility is that non-thermal desorptive processes, such as desorption via the energy generated by exothermic chemical reactions on granular surfaces (Garrod et al. 2007), can lead to sufficient concentrations of these molecules (or their precursors) in the gasphase. For the case of TMC-1, grain chemistry followed by nonthermal desorption is the only known manner in which gaseous methanol can be produced. Another possibility often invoked when discussing the galactic center region is that intermittent shock waves pervade the medium and sputter molecules off of grain surfaces. Yet a third possibility is that the molecules are formed in the warmer (hot core) region and then diffuse throughout the halo. The hot core gas-grain model of Garrod \& Herbst (2006) only requires surface temperatures of $40 \mathrm{~K}$ or so for the production of organic molecules; in this model temperatures greater than $10 \mathrm{~K}$ are needed for radicals on grains to diffuse and react to form the larger species. Once these molecules are formed on a surface of $40 \mathrm{~K}$ or so, they can be desorbed by shock waves. To determine which if any of these alternative explanations are correct for Sgr B2(N) will require a deeper understanding of the 
chemical and physical processes involved and more detailed observations of molecules surrounding hot-core sources.

Acknowledgements. We thank D. Talbi for her quantum chemical calculations regarding the formation of cyclopropenone, M. McEwan for information about the association reaction between $\mathrm{C}_{2} \mathrm{H}_{3}^{+}$and $\mathrm{CO}$, and $\mathrm{J}$. M. Hollis for reading an earlier version of this manuscript. E. H. acknowledges the support of the National Science Foundation (US) for his research program in astrochemistry.

\section{References}

Adams, N. G., Smith, D., \& Paulson, J. F. 1980, J. Chem. Phys., 72, 288 Adams, N. G., Babcock, L. M., Mostefaouoi, T. M., \& Kerns, M. S. 2003, Int. J. Mass. Spectrom., 223, 459

Balucani, N., Asvany, O., Kaiser, R.-I., \& Osamura, Y. 2002, J. Phys. Chem. A, 106,4301

Carty, D., Le Page, V., Sims, I. R., \& Smith, I. W. M. 2001, Chem. Phys. Lett., 344,310

Chesnavich, W. J., Su, T., \& Bowers, M. T. 1980, J. Chem. Phys., 72, 2641

Chin, Y., Kaiser, R. I., Lemme, C., \& Henkel, C. 2006, in Astrochemistry, From Laboratory Studies to Astronomical Observations, AIP Conf. Proc., 855, 149 Garrod, R. T., \& Herbst, E. 2006, A\&A, 457, 927
Garrod, R. T., Wakelam, V., \& Herbst, E. 2007, A\&A, 467, 1103

Graedel, T. E., Langer, W. D., \& Frerking, M. A. 1982, ApJS, 48, 321

Hollis, J. M., Jewell, P. R., Lovas, F. J., Remijan, A., \& Møllendal, H. 2004, ApJ, 610, L21

Hollis, J. M., Remijan, A. J., Jewell, P. R., \& Lovas, F. J. 2006a, ApJ, 642, 933

Hollis, J. M., Lovas, F. J., Remijan, A. J., et al. 2006b, ApJ, 643, L25

Laufer, A. H., \& Fahr, A. 2004, Chem. Rev., 104, 2813

Lovas, F. J., Remijan, A. J., Hollis, J. M., Jewell, P. R., \& Snyder, L. E. 2006a, ApJ, 637, L37

Lovas, F. J., Hollis, J. M., Remijan, A. J., \& Jewell, P. R. 2006b, ApJ, 645, L137 Prodnuk, S. D., Gronert, S., Bierbaum, V. M., \& DePuy, C. H. 1992, Org. Mass. Spectrom., 27, 416

Remijan, A. J., Hollis, J. M., Snyder, L. E., Jewell, P. R., \& Lovas, F. J. 2006, ApJ, 643, L37

Schwahn, G., Schieder, R., Bester, M., \& Winnewisser, G. 1986, J. Mol. Spectrosc., 116, 263

Scott, G. B. I., Fairley, D. A., Freeman, C. G., Maclagan, R. G. A. R., \& McEwan, M. J. 1995, IJMSIP, 149/150, 251

Snyder, L. E., Wilson, T. L., Henkel, C., Jewell, P. R., \& Walmsley, C. M. 1984, BAAS, 16, 959

Snyder, L. E., Hollis, J. M., Jewell, P. R., Lovas, F. J., \& Remijan, A. 2006, ApJ, 647,412

Wakelam, V., Herbst, E., \& Selsis, F. 2006, A\&A, 451, 551 
D. Quan and E. Herbst: Possible gas-phase syntheses for seven GBT molecules, Online Material p 1

\section{Online Material}


D. Quan and E. Herbst: Possible gas-phase syntheses for seven GBT molecules, Online Material p 2

Table 2. Reactions involving GBT molecules and their protonated ions.

\begin{tabular}{|c|c|c|c|c|}
\hline Reaction & $\overline{\alpha \alpha}$ & $\overline{\bar{\beta}}$ & $\overline{\gamma \gamma}$ & $\overline{\text { Ref. }}$ \\
\hline $\mathrm{C}_{3} \mathrm{H}_{4}+\mathrm{CN} \rightarrow \mathrm{C}_{4} \mathrm{H}_{3} \mathrm{~N}+\mathrm{H}$ & $4.10 \times 10^{-1}$ & 0 & 0 & 1 \\
\hline $\mathrm{C}_{4} \mathrm{H}_{3} \mathrm{~N} \rightarrow \mathrm{C}_{3} \mathrm{~N}+\mathrm{CH}_{3}$ & $1.50 \times 10^{3}$ & 0 & 0 & 2 \\
\hline $\mathrm{C}_{4} \mathrm{H}_{3} \mathrm{~N}+\mathrm{H}_{3}^{+} \rightarrow \mathrm{C}_{4} \mathrm{H}_{4} \mathrm{~N}^{+}+\mathrm{H}_{2}$ & $1.08 \times 10^{-8}$ & -0.5 & 0 & 2 \\
\hline $\mathrm{C}_{4} \mathrm{H}_{3} \mathrm{~N}+\mathrm{HCO}^{+} \rightarrow \mathrm{C}_{4} \mathrm{H}_{4} \mathrm{~N}^{+}+\mathrm{CO}$ & $4.11 \times 10^{-9}$ & -0.5 & 0 & 2 \\
\hline $\mathrm{C}_{4} \mathrm{H}_{3} \mathrm{~N}+\mathrm{He}^{+} \rightarrow \mathrm{CH}_{3}^{+}+\mathrm{C}_{3} \mathrm{~N}+\mathrm{He}$ & $9.49 \times 10^{-9}$ & -0.5 & 0 & 2 \\
\hline $\mathrm{C}_{4} \mathrm{H}_{3} \mathrm{~N}+\mathrm{H}^{+} \rightarrow \mathrm{CH}_{3}^{+}+\mathrm{HC}_{3} \mathrm{~N}$ & $1.85 \times 10^{-8}$ & -0.5 & 0 & 2 \\
\hline $\mathrm{C}_{4} \mathrm{H}_{3} \mathrm{~N}+\mathrm{C}^{+} \rightarrow \mathrm{C}_{2} \mathrm{H}_{3}^{+}+\mathrm{C}_{3} \mathrm{~N}$ & $2.90 \times 10^{-9}$ & -0.5 & 0 & 2 \\
\hline $\mathrm{C}_{4} \mathrm{H}_{3} \mathrm{~N}+\mathrm{C}^{+} \rightarrow \mathrm{C}_{4} \mathrm{H}_{3}^{+}+\mathrm{CN}$ & $2.90 \times 10^{-9}$ & -0.5 & 0 & 2 \\
\hline $\mathrm{C}_{4} \mathrm{H}_{3} \mathrm{~N}^{+}+\mathrm{H}_{2} \rightarrow \mathrm{C}_{4} \mathrm{H}_{4} \mathrm{~N}^{+}+\mathrm{H}$ & $1.00 \times 10^{-9}$ & 0 & 0 & 2 \\
\hline $\mathrm{C}_{4} \mathrm{H}_{5}^{+}+\mathrm{N} \rightarrow \mathrm{C}_{4} \mathrm{H}_{4} \mathrm{~N}^{+}+\mathrm{H}$ & $1.00 \times 10^{-10}$ & 0 & 0 & 2 \\
\hline $\mathrm{CH}_{3}^{+}+\mathrm{HC}_{3} \mathrm{~N} \rightarrow \mathrm{C}_{4} \mathrm{H}_{4} \mathrm{~N}^{+}+\mathrm{h} v$ & $8.60 \times 10^{-11}$ & -1.4 & 0 & 2 \\
\hline $\mathrm{C}_{4} \stackrel{3}{4}_{4} \mathrm{~N}^{+}+\mathrm{C} \rightarrow \mathrm{C}_{5} \mathrm{H}_{3} \mathrm{~N}^{+}+\mathrm{H}$ & $1.00 \times 10^{-9}$ & 0 & 0 & 2 \\
\hline $\mathrm{C}_{4} \mathrm{H}_{4} \mathrm{~N}^{+}+\mathrm{e}^{-} \rightarrow \mathrm{C}_{4} \mathrm{H}_{3} \mathrm{~N}+\mathrm{H}$ & $1.00 \times 10^{-6}$ & -0.3 & 0 & 2 \\
\hline $\mathrm{C}_{4} \mathrm{H}_{4} \mathrm{~N}^{+}+\mathrm{e}^{-} \rightarrow \mathrm{CH}_{3}+\mathrm{HC}_{3} \mathrm{~N}$ & $1.00 \times 10^{-6}$ & -0.3 & 0 & 2 \\
\hline $\mathrm{CH}_{3} \mathrm{C}_{4} \mathrm{H}+\mathrm{CN} \rightarrow \mathrm{CH}_{3} \mathrm{C}_{5} \mathrm{~N}+\mathrm{H}$ & $4.10 \times 10^{-10}$ & 0 & 0 & 1,3 \\
\hline $\mathrm{CH}_{3} \mathrm{C}_{5} \mathrm{~N} \rightarrow \mathrm{C}_{5} \mathrm{~N}+\mathrm{CH}_{3}$ & $1.50 \times 10^{3}$ & 0 & 0 & 2 \\
\hline $\mathrm{CH}_{3} \mathrm{C}_{5} \mathrm{~N}+\mathrm{C}^{+} \rightarrow \mathrm{C}_{6} \mathrm{H}_{3}^{+}+\mathrm{CN}$ & $6.24 \times 10^{-9}$ & -0.5 & 0 & 2 \\
\hline $\mathrm{CH}_{3} \mathrm{C}_{5} \mathrm{~N}+\mathrm{H}^{+} \rightarrow \mathrm{CH}_{3}^{+}+\mathrm{HC}_{5} \mathrm{~N}$ & $2.03 \times 10^{-8}$ & -0.5 & 0 & 2 \\
\hline $\mathrm{CH}_{3} \mathrm{C}_{5} \mathrm{~N}+\mathrm{He}^{+} \rightarrow \mathrm{CH}_{3}^{+}+\mathrm{C}_{5} \mathrm{~N}+\mathrm{He}$ & $1.04 \times 10^{-8}$ & -0.5 & 0 & 2 \\
\hline $\mathrm{CH}_{3} \mathrm{C}_{5} \mathrm{~N}+\mathrm{H}_{3}^{+} \rightarrow \mathrm{C}_{6} \mathrm{H}_{4} \mathrm{~N}^{+}+\mathrm{H}_{2}$ & $1.19 \times 10^{-8}$ & -0.5 & 0 & 2 \\
\hline $\mathrm{CH}_{3} \mathrm{C}_{5} \mathrm{~N}+\mathrm{HCO}^{+} \rightarrow \mathrm{C}_{6} \mathrm{H}_{4} \mathrm{~N}^{+}+\mathrm{CO}$ & $4.34 \times 10^{-9}$ & -0.5 & 0 & 2 \\
\hline $\mathrm{C}_{6} \mathrm{H}_{5}^{+}+\mathrm{N} \rightarrow \mathrm{C}_{6} \mathrm{H}_{4} \mathrm{~N}^{+}+\mathrm{H}$ & $1.00 \times 10^{-10}$ & 0 & 0 & 2 \\
\hline $\mathrm{CH}_{3}^{+}+\mathrm{HC}_{5} \mathrm{~N} \rightarrow \mathrm{C}_{6} \mathrm{H}_{4} \mathrm{~N}^{+}+\mathrm{h} v$ & $8.60 \times 10^{-11}$ & -1.4 & 0 & 2 \\
\hline $\mathrm{C}_{6} \mathrm{H}_{4} \mathrm{~N}^{+}+\mathrm{C} \rightarrow \mathrm{C}_{7} \mathrm{H}_{3} \mathrm{~N}^{+}+\mathrm{H}$ & $1.00 \times 10^{-9}$ & 0 & 0 & 2 \\
\hline $\mathrm{C}_{6} \mathrm{H}_{4} \mathrm{~N}^{+}+\mathrm{e}^{-} \rightarrow \mathrm{CH}_{3}+\mathrm{HC}_{5} \mathrm{~N}$ & $1.00 \times 10^{-6}$ & -0.3 & 0 & 2 \\
\hline $\mathrm{C}_{6} \mathrm{H}_{4} \mathrm{~N}^{+}+\mathrm{e}^{-} \rightarrow \mathrm{CH}_{3} \mathrm{C}_{5} \mathrm{~N}+\mathrm{H}$ & $1.00 \times 10^{-6}$ & -0.3 & 0 & 2 \\
\hline $\mathrm{CCH}+\mathrm{CH}_{3} \mathrm{C}_{4} \mathrm{H} \rightarrow \mathrm{CH}_{3} \mathrm{C}_{6} \mathrm{H}+\mathrm{H}$ & $1.80 \times 10^{-10}$ & 0 & 0 & 1,3 \\
\hline $\mathrm{C}_{6} \mathrm{H}+\mathrm{CH}_{4} \rightarrow \mathrm{CH}_{3} \mathrm{C}_{6} \mathrm{H}+\mathrm{H}$ & $7.00 \times 10^{-12}$ & 0 & 0 & 3 \\
\hline $\mathrm{C}_{7} \mathrm{H}_{5}^{+}+\mathrm{e}^{-} \rightarrow \mathrm{CH}_{3} \mathrm{C}_{6} \mathrm{H}+\mathrm{H}$ & $3.50 \times 10^{-7}$ & -0.5 & 0 & 2 \\
\hline $\mathrm{C}_{7} \mathrm{H}_{5}^{+}+\mathrm{e}^{-} \rightarrow \mathrm{C}_{7} \mathrm{H}_{2}+\mathrm{H}_{2}+\mathrm{H}$ & $3.50 \times 10^{-7}$ & -0.5 & 0 & 2 \\
\hline $\mathrm{C}_{2} \mathrm{H}_{4}^{+}+\mathrm{C}_{5} \mathrm{H}_{2} \rightarrow \mathrm{C}_{7} \mathrm{H}_{5}^{+}+\mathrm{H}$ & $5.52 \times 10^{-10}$ & -0.5 & 0 & 2 \\
\hline $\mathrm{C}_{4} \mathrm{H}_{2}^{+}+\mathrm{C}_{3} \mathrm{H}_{4} \rightarrow \mathrm{C}_{7} \mathrm{H}_{5}^{+}+\mathrm{H}$ & $6.42 \times 10^{-10}$ & -0.5 & 0 & 2 \\
\hline $\mathrm{C}_{4} \mathrm{H}_{3}^{+}+\mathrm{C}_{3} \mathrm{H}_{3} \rightarrow \mathrm{C}_{7} \mathrm{H}_{5}^{+}+\mathrm{H}$ & $1.65 \times 10^{-9}$ & -0.5 & 0 & 2 \\
\hline $\mathrm{C}_{5} \mathrm{H}_{2}^{+}+\mathrm{C}_{2} \mathrm{H}_{4} \rightarrow \mathrm{C}_{7} \mathrm{H}_{5}^{+}+\mathrm{H}$ & $5.00 \times 10^{-10}$ & 0 & 0 & 2 \\
\hline $\mathrm{C}_{6} \mathrm{H}_{2}^{+}+\mathrm{CH}_{4} \rightarrow \mathrm{C}_{7} \mathrm{H}_{5}^{+}+\mathrm{H}$ & $8.00 \times 10^{-10}$ & 0 & 0 & 2 \\
\hline $\mathrm{C}_{3} \mathrm{H}_{3}^{+}+\mathrm{C}_{4} \mathrm{H}_{2} \rightarrow \mathrm{C}_{7} \mathrm{H}_{5}^{+}+\mathrm{h} v$ & $1.00 \times 10^{-13}$ & -2.5 & 0 & 2 \\
\hline $\mathrm{C}_{5} \mathrm{H}_{3}^{+}+\mathrm{C}_{2} \mathrm{H}_{2} \rightarrow \mathrm{C}_{7} \mathrm{H}_{5}^{+}+\mathrm{h} v$ & $1.00 \times 10^{-9}$ & 0 & 0 & 3 \\
\hline $\mathrm{C}_{7} \mathrm{H}_{5}^{+}+\mathrm{N} \rightarrow \mathrm{C}_{7} \mathrm{H}_{3} \mathrm{~N}^{+}+\mathrm{H}_{2}$ & $1.00 \times 10^{-10}$ & 0 & 0 & 2 \\
\hline $\mathrm{CH}_{3} \mathrm{C}_{6} \mathrm{H} \rightarrow \mathrm{C}_{6} \mathrm{H}+\mathrm{CH}_{3}$ & $1.50 \times 10^{3}$ & 0 & 0 & 2 \\
\hline $\mathrm{CH}_{3} \mathrm{C}_{6} \mathrm{H}+\mathrm{C}^{+} \rightarrow \mathrm{C}_{7} \mathrm{H}_{3}^{+}+\mathrm{CH}$ & $9.00 \times 10^{-10}$ & -0.5 & 0 & 2 \\
\hline $\mathrm{CH}_{3} \mathrm{C}_{6} \mathrm{H}+\mathrm{C}^{+} \rightarrow \mathrm{C}_{8} \mathrm{H}_{2}^{+}+\mathrm{H}_{2}$ & $9.00 \times 10^{-10}$ & -0.5 & 0 & 2 \\
\hline $\mathrm{CH}_{3} \mathrm{C}_{6} \mathrm{H}+\mathrm{H}^{+} \rightarrow \mathrm{C}_{7} \mathrm{H}_{3}^{+}+\mathrm{H}_{2}$ & $2.92 \times 10^{-9}$ & -0.5 & 0 & 2 \\
\hline $\mathrm{CH}_{3} \mathrm{C}_{6} \mathrm{H}+\mathrm{H}^{+} \rightarrow \mathrm{C}_{7} \mathrm{H}_{4}^{+}+\mathrm{H}$ & $2.92 \times 10^{-9}$ & -0.5 & 0 & 2 \\
\hline $\mathrm{CH}_{3} \mathrm{C}_{6} \mathrm{H}+\mathrm{He}^{+} \rightarrow \mathrm{C}_{7} \mathrm{H}_{2}^{+}+\mathrm{H}_{2}+\mathrm{He}$ & $1.49 \times 10^{-9}$ & -0.5 & 0 & 2 \\
\hline $\mathrm{CH}_{3} \mathrm{C}_{6} \mathrm{H}+\mathrm{He}^{+} \rightarrow \mathrm{C}_{7} \mathrm{H}_{3}^{+}+\mathrm{H}+\mathrm{He}$ & $1.49 \times 10^{-9}$ & -0.5 & 0 & 2 \\
\hline $\mathrm{CH}_{3} \mathrm{C}_{6} \mathrm{H}+\mathrm{H}_{3}^{+} \rightarrow \mathrm{C}_{7} \mathrm{H}_{5}^{+}+\mathrm{H}_{2}$ & $3.40 \times 10^{-9}$ & -0.5 & 0 & 2 \\
\hline $\mathrm{CH}_{3} \mathrm{C}_{6} \mathrm{H}+\mathrm{HCO}^{+} \rightarrow \mathrm{C}_{7} \mathrm{H}_{5}^{+}+\mathrm{CO}$ & $1.25 \times 10^{-9}$ & -0.5 & 0 & 2 \\
\hline $\mathrm{CH}_{3} \mathrm{C}_{6} \mathrm{H}+\mathrm{C} \rightarrow \mathrm{C}_{8} \mathrm{H}_{2}+\mathrm{H}_{2}$ & $7.40 \times 10^{-10}$ & 0 & 0 & 2 \\
\hline $\mathrm{CH}_{3} \mathrm{CNH}^{+}+\mathrm{e}^{-} \rightarrow \mathrm{CH}_{2} \mathrm{CNH}+\mathrm{H}$ & $1.00 \times 10^{-7}$ & -0.5 & 0 & 3 \\
\hline $\mathrm{CH}_{2} \mathrm{CNH}+\mathrm{C}^{+} \rightarrow \mathrm{C}_{2} \mathrm{H}_{3}^{+}+\mathrm{CN}$ & $1.83 \times 10^{-9}$ & -0.5 & 0 & 4 \\
\hline $\mathrm{CH}_{2} \mathrm{CNH}+\mathrm{H}^{+} \rightarrow \mathrm{CH}_{2} \mathrm{CN}^{+}+\mathrm{H}_{2}$ & $2.82 \times 10^{-9}$ & -0.5 & 0 & 4 \\
\hline $\mathrm{CH}_{2} \mathrm{CNH}+\mathrm{H}^{+} \rightarrow \mathrm{CH}_{3} \mathrm{CN}^{+}+\mathrm{H}$ & $2.82 \times 10^{-9}$ & -0.5 & 0 & 4 \\
\hline $\mathrm{CH}_{2} \mathrm{CNH}+\mathrm{He}^{+} \rightarrow \mathrm{CN}^{+}+\mathrm{CH}_{3}+\mathrm{He}$ & $2.02 \times 10^{-9}$ & -0.5 & 0 & 4 \\
\hline $\mathrm{CH}_{2} \mathrm{CNH}+\mathrm{He}^{+} \rightarrow \mathrm{CH}_{3}^{+}+\mathrm{CN}+\mathrm{He}$ & $2.02 \times 10^{-9}$ & -0.5 & 0 & 4 \\
\hline
\end{tabular}


D. Quan and E. Herbst: Possible gas-phase syntheses for seven GBT molecules, Online Material p 3

Table 2. continued.

\begin{tabular}{|c|c|c|c|c|}
\hline Reaction & $\overline{\alpha \alpha}$ & $\overline{\bar{\beta}}$ & $\overline{\gamma \gamma}$ & 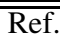 \\
\hline $\mathrm{CH}_{2} \mathrm{CNH}+\mathrm{H}_{3}^{+} \rightarrow \mathrm{CH}_{3} \mathrm{CNH}^{+}+\mathrm{H}_{2}$ & $3.33 \times 10^{-9}$ & -0.5 & 0 & 4 \\
\hline $\mathrm{CH}_{2} \mathrm{CNH}+\mathrm{HCO}^{+} \rightarrow \mathrm{CH}_{3} \mathrm{CNH}^{+}+\mathrm{CO}$ & $1.35 \times 10^{-9}$ & -0.5 & 0 & 4 \\
\hline $\mathrm{HCN}+\mathrm{CH}_{3}^{+} \rightarrow \mathrm{CH}_{3} \mathrm{CNH}^{+}+\mathrm{h} v$ & $9.00 \times 10^{-9}$ & -0.5 & 0 & 2 \\
\hline $\mathrm{CH}_{3} \mathrm{CNH}^{+}+\mathrm{e}^{-} \rightarrow \mathrm{CH}_{2} \mathrm{CN}+\mathrm{H}+\mathrm{H}$ & $1.00 \times 10^{-7}$ & -0.5 & 0 & 3 \\
\hline $\mathrm{CH}_{3} \mathrm{CNH}^{+}+\mathrm{e}^{-} \rightarrow \mathrm{CH}_{3} \mathrm{CN}+\mathrm{H}$ & $1.00 \times 10^{-7}$ & -0.5 & 0 & 3 \\
\hline $\mathrm{CH}_{3} \mathrm{CN}+\mathrm{H}_{3}^{+} \rightarrow \mathrm{CH}_{3} \mathrm{CNH}^{+}+\mathrm{H}_{2}$ & $9.10 \times 10^{-9}$ & -0.5 & 0 & 2 \\
\hline $\mathrm{CH}_{3} \mathrm{CN}+\mathrm{HCO}^{+} \rightarrow \mathrm{CH}_{3} \mathrm{CNH}^{+}+\mathrm{CO}$ & $3.70 \times 10^{-9}$ & -0.5 & 0 & 2 \\
\hline $\mathrm{CH}_{3} \mathrm{CN}+\mathrm{H}_{3} \mathrm{O}^{+} \rightarrow \mathrm{CH}_{3} \mathrm{CNH}^{+}+\mathrm{H}_{2} \mathrm{O}$ & $4.22 \times 10^{-9}$ & -0.5 & 0 & 2 \\
\hline $\mathrm{CH}_{3} \mathrm{CN}+\mathrm{HOCO}^{+} \rightarrow \mathrm{CH}_{3} \mathrm{CNH}^{+}+\mathrm{CO}_{2}$ & $3.28 \times 10^{-9}$ & -0.5 & 0 & 2 \\
\hline $\mathrm{c}-\mathrm{C}_{3} \mathrm{H}_{2}+\mathrm{OH} \rightarrow \mathrm{c}-\mathrm{C}_{3} \mathrm{H}_{2} \mathrm{O}+\mathrm{H}$ & $1.00 \times 10^{-11}$ & 0 & 0 & 5 \\
\hline $\mathrm{c}-\mathrm{C}_{3} \mathrm{H}_{4}^{+}+\mathrm{O} \rightarrow \mathrm{c}-\mathrm{C}_{3} \mathrm{H}_{3} \mathrm{O}^{+}+\mathrm{H}$ & $2.00 \times 10^{-10}$ & 0 & 0 & 6 \\
\hline $\mathrm{C}_{2} \mathrm{H}_{3}^{+}+\mathrm{CO} \rightarrow \mathrm{c}-\mathrm{C}_{3} \mathrm{H}_{3} \mathrm{O}^{+}+\mathrm{h} v$ & $2.00 \times 10^{-16}$ & -2.5 & 0 & 7 \\
\hline $\mathrm{c}-\mathrm{C}_{3} \mathrm{H}_{3} \mathrm{O}^{+}+\mathrm{e}^{-} \rightarrow \mathrm{c}-\mathrm{C}_{3} \mathrm{H}_{2} \mathrm{O}+\mathrm{H}$ & $1.00 \times 10^{-7}$ & -0.5 & 0 & 3 \\
\hline $\mathrm{c}-\mathrm{C}_{3} \mathrm{H}_{3} \mathrm{O}^{+}+\mathrm{e}^{-} \rightarrow \mathrm{C}_{2} \mathrm{H}_{3}+\mathrm{CO}$ & $1.00 \times 10^{-7}$ & -0.5 & 0 & 3 \\
\hline $\mathrm{c}-\mathrm{C}_{3} \mathrm{H}_{2} \mathrm{O}+\mathrm{H}_{3}^{+} \rightarrow \mathrm{c}-\mathrm{C}_{3} \mathrm{H}_{3} \mathrm{O}^{+}+\mathrm{H}_{2}$ & $1.01 \times 10^{-8}$ & -0.5 & 0 & 4 \\
\hline $\mathrm{c}-\mathrm{C}_{3} \mathrm{H}_{2} \mathrm{O}+\mathrm{HCO}^{+} \rightarrow \mathrm{c}-\mathrm{C}_{3} \mathrm{H}_{3} \mathrm{O}^{+}+\mathrm{CO}$ & $3.91 \times 10^{-9}$ & -0.5 & 0 & 4 \\
\hline $\mathrm{c}-\mathrm{C}_{3} \mathrm{H}_{2} \mathrm{O}+\mathrm{H}_{3} \mathrm{O}^{+} \rightarrow \mathrm{c}-\mathrm{C}_{3} \mathrm{H}_{3} \mathrm{O}^{+}+\mathrm{H}_{2} \mathrm{O}$ & $4.29 \times 10^{-9}$ & -0.5 & 0 & 4 \\
\hline $\mathrm{c}-\mathrm{C}_{3} \mathrm{H}_{2} \mathrm{O}+\mathrm{He}^{+} \rightarrow \mathrm{C}_{3} \mathrm{H}_{2}^{+}+\mathrm{O}+\mathrm{He}$ & $1.22 \times 10^{-8}$ & -0.5 & 0 & 4 \\
\hline $\mathrm{c}-\mathrm{C}_{3} \mathrm{H}_{2} \mathrm{O}+\mathrm{H}^{+} \rightarrow \mathrm{C}_{3} \mathrm{H}_{2}^{+}+\mathrm{OH}$ & $1.71 \times 10^{-8}$ & -0.5 & 0 & 4 \\
\hline $\mathrm{c}-\mathrm{C}_{3} \mathrm{H}_{2} \mathrm{O}+\mathrm{C}^{+} \rightarrow \mathrm{C}_{3} \mathrm{H}_{2}^{+}+\mathrm{CO}$ & $5.41 \times 10^{-9}$ & -0.5 & 0 & 4 \\
\hline $\mathrm{NH}_{2} \mathrm{CHO}+\mathrm{CH}_{3}^{+} \rightarrow \mathrm{CH}_{3} \mathrm{CHONH}_{2}^{+}+\mathrm{h} v$ & $1.00 \times 10^{-9}$ & 0 & 0 & 3 \\
\hline $\mathrm{CH}_{3} \mathrm{CHONH}_{2}^{+}+\mathrm{e}^{-} \rightarrow \mathrm{CH}_{3} \mathrm{CONH}_{2}+\mathrm{H}$ & $1.00 \times 10^{-7}$ & -0.5 & 0 & 3 \\
\hline $\mathrm{CH}_{3} \mathrm{CHONH}_{2}^{+}+\mathrm{e}^{-} \rightarrow \mathrm{CH}_{3}+\mathrm{NH}_{2} \mathrm{CHO}$ & $1.00 \times 10^{-7}$ & -0.5 & 0 & 3 \\
\hline $\mathrm{CH}_{3} \mathrm{CHO}+\mathrm{NH}_{4}^{+} \rightarrow \mathrm{CH}_{3} \mathrm{CHONH}_{4}^{+}+\mathrm{h} v$ & $1.00 \times 10^{-13}$ & -3.0 & 0 & 8 \\
\hline $\mathrm{CH}_{3} \mathrm{CHONH}_{4}^{+}+\mathrm{e}^{-} \rightarrow \mathrm{CH}_{3} \mathrm{CONH}_{2}+\mathrm{H}_{2}+\mathrm{H}$ & $1.00 \times 10^{-7}$ & -0.5 & 0 & 3 \\
\hline $\mathrm{CH}_{3} \mathrm{CHONH}_{4}^{+}+\mathrm{e}^{-} \rightarrow \mathrm{CH}_{3}+\mathrm{NH}_{2} \mathrm{CHO}+\mathrm{H}_{2}$ & $1.00 \times 10^{-7}$ & -0.5 & 0 & 3 \\
\hline $\mathrm{CH}_{3} \mathrm{CONH}_{2}+\mathrm{C}^{+} \rightarrow \mathrm{CH}_{3} \mathrm{CONH}_{2}^{+}+\mathrm{C}$ & $4.60 \times 10^{-9}$ & -0.5 & 0 & 4 \\
\hline $\mathrm{CH}_{3} \mathrm{CONH}_{2}+\mathrm{H}^{+} \rightarrow \mathrm{CH}_{3} \mathrm{CONH}_{2}^{+}+\mathrm{H}$ & $1.47 \times 10^{-8}$ & -0.5 & 0 & 4 \\
\hline $\mathrm{CH}_{3} \mathrm{CONH}_{2}+\mathrm{He}^{+} \rightarrow \mathrm{CH}_{3} \mathrm{CONH}_{2}^{+}+\mathrm{He}$ & $5.20 \times 10^{-9}$ & -0.5 & 0 & 4 \\
\hline $\mathrm{CH}_{3} \mathrm{CONH}_{2}+\mathrm{He}^{+} \rightarrow \mathrm{CH}_{3}^{+}+\mathrm{CO}+\mathrm{NH}_{2}+\mathrm{He}$ & $5.20 \times 10^{-9}$ & -0.5 & 0 & 4 \\
\hline $\mathrm{CH}_{3} \mathrm{CONH}_{2}+\mathrm{H}_{3}^{+} \rightarrow \mathrm{CH}_{3} \mathrm{CHONH}_{2}^{+}+\mathrm{H}_{2}$ & $8.60 \times 10^{-9}$ & -0.5 & 0 & 4 \\
\hline $\mathrm{CH}_{3} \mathrm{CONH}_{2}+\mathrm{HCO}^{+} \rightarrow \mathrm{CH}_{3} \mathrm{CHONH}_{2}^{+}+\mathrm{CO}$ & $3.30 \times 10^{-8}$ & -0.5 & 0 & 4 \\
\hline $\mathrm{CH}_{3} \mathrm{CONH}_{2}^{+}+\mathrm{H}_{2} \rightarrow \mathrm{CH}_{3} \mathrm{CHONH}_{2}^{+}+\mathrm{H}$ & $1.00 \times 10^{-9}$ & 0 & 0 & 3 \\
\hline $\mathrm{CH}_{3} \mathrm{CONH}_{2}^{+}+\mathrm{e}^{-} \rightarrow \mathrm{CH}_{3}+\mathrm{NH}_{2}+\mathrm{CO}$ & $1.50 \times 10^{-7}$ & -0.5 & 0 & 3 \\
\hline
\end{tabular}

NOTE : The parameter $\alpha$ is in units of $\mathrm{cm}^{3} \mathrm{~s}^{-1}$ for bimolecular reactions and is unitless for cosmic ray processes. ${ }^{1}$ Ref. Carty et al. (2001); 2 osu.01.2007; ${ }^{3}$ estimation according to analogous reaction rates; ${ }^{4}$ calculation based on method of Chesnavich et al. (1980); ${ }^{5}$ Ref. D. Talbi, private communication; ${ }^{6}$ Ref. Prodnuk et al. (1992); ${ }^{7}$ Ref. Scott et al. (1995); ${ }^{8}$ Ref. Adams et al. (2003). 